\title{
PEMBELAJARAN DRAMA DI KELAS XI IBB SMA NEGERI 1 TEJAKULA
}

\author{
Ayu Widiastawa, I Nengah Martha, Ni Made Rai Wisudariani \\ Jurusan Pendidikan Bahasa dan Sastra Indonesia \\ Falkutas Bahasa dan Seni \\ Universitas Pendidikan Ganesha \\ Singaraja, Indonesia \\ e-mail :ayuwidiastawa63@gmail.com, nengahmartha@yahoo.com, \\ rai.wisudariani85@gmail.com
}

\begin{abstract}
ABSTRAK
Penelitian ini bertujuan mendeskripsikan : (1) perencanaan pembelajaran drama, (2) pelaksanaan pembelajaran drama, (3) hasil evaluasi pembelajaran drama, (4) teknik evaluasi pembelajaran drama. Penelitian ini menggunakan rancangan penelitian deskriptif kualitatif. Subjek dalam penelitian ini adalah guru mata pelajaran bahasa Indonesia yang mengajar di kelas XI IBB SMA Negeri 1 Tejakula. Objek penelitian ini adalah perencanaan, pelaksanaan, hasil evaluasi, dan teknik evaluasi dalam pembelajaran drama. Metode pengumpulan data yang digunakan adalah wawancara, observasi, dan dokumentasi. Analisis data dalam penelitian ini mencakup tiga hal, yaitu reduksi data, penyajian data, dan penarikan kesimpulan. Berdasarkan hasil penelitian, dapat disimpulkan bahwa (1) perencanaan pembelajaran drama yang dilakukan oleh guru sudah sesuai dengan menyusun perangkat pembelajaran yang terdiri atas silabus, RPP, media pembelajaran, dan evaluasi. (2) pelaksanaan pembelajaran yang dilakukan oleh guru sudah sesuai dengan langkah-langkah kegiatan pembelajaran yang tertera pada RPP meliputi : pendahuluan, inti, dan penutup. (3) hasil evaluasi pembelajaran drama yang dilakukan guru sudah sangat baik, peserta didik sangat antusias mengikuti pembelajaran, nilai peserta didik di atas KKM, tidak ada siswa yang remidi, 6 orang siswa memperoleh nilai tertinggi dengan nilai 95. Peserta didik yang lain memperoleh nilai 70 sampai 80 . (4) teknik evaluasi pembelajaran yang dilakukan oleh guru meliputi penilaian sikap pengetahuan, keterampilan, remedial dan pengayaan. Menggunakan metode penilaian observasi, penilaian diri, penilaian antartema, tes lisan, penugasan, tes tertulis, portofolio, praktik, produk, dan proyek.Disarankan, guru dapat mengikuti cara ini dalam melakukan pembelajaran drama.
\end{abstract}

Kata kunci :pembelajarandrama

\section{ABSTRACK}

This research aims to describe : (1) the lesson plan of learning drama, (2) the process of learning drama, (3) the evaluation result of learning drama, (4) the evaluation technique of learning drama. It is arranged by using the descriptive qualitative method. The subject of this research are Indonesia language teachers of grade XI IBB in SMA Negeri 1 


\begin{abstract}
Tejakula. The object of this research are the planning, the process, the evaluation result as well as the evaluation technique in learning drama. The metholodogies used in collecting the data are interview, observation, and documentation. The data analysis of the research is including 3 points which are data reduction, data presentation and conclusion. Based on the result of this research, it can be concluded that (1) The lesson plan of learning drama is appropriately prepared by the teacher including the arrangement of learning equipment such as syllabus, lesson plans, teaching media and evaluation. (2) The execution of learning activity done by the teacher has met the procedures of learning process stated on the lesson plan which involves pre-activity, whilst-activity and post-activity. (3) The results of the learning evaluation carried out by the teacher is really good, the students were really interested during the learning process and the all could collect scores more than the standard scores (KKM), There is no student need to repeat the class, 6 students are getting the highest score of 95, while the rest could reach 70 to 80 of score. (4) The technique ofthe learning evaluation carried out by the teacher include assessment of attitudes, knowledge, skills, remedial and enrichment. Using methods of observation, self-assessment, interagency assessment, oral tests, assignments, written tests, portfolios, practices, products, and projects.

Sugestek, the teacher can be following then manners on teaching and learning of drama.
\end{abstract}

\title{
Keywords :learning drama
}

\section{PENDAHULUAN}

Pembelajaran Bahasa Indonesia merupakan salah satu materi pelajaran yang sangat penting di sekolah. Dengan mengikuti pembelajaran Bahasa Indonesia, peserta didik diharapkan agar menjadi manusia yang dapat saling berkomunikasi, saling berbagi pengalaman, saling belajar dari yang lain, meningkatkan kemampuan intelektual dan kesusasteraan. Pada jenjang SMA pembelajaran Bahasa Indonesia diarahkan agar (1) siswa memiliki kemampuan berbahasa Indonesia yang baik dan benar sesuai situasi dan tujuan, (2) siswa mampu mengembangkan kemampuan berbahasa Indonesianya sesuai dengan kebutuhan dan minat, (3) siswa dapat membaca memanfaatkan karya sastra untuk memperluas wawasan, memperbaiki budi pekerti, serta meningkatkatkan pengetahuan dan kemampuan berbahasa.

Pembelajaran sastra merupakan hal yang sangat berguna, bermanfaat, serta dibutuhkan oleh siswa dalam kehidupan sehari-hari, khususnya di lingkungan sekolah. Sastra pada hakikatnya merupakan hasil karya yang lahir dari sebuah ide, gagasan/imajinasi pengarang, mengenai yang dilihat, dialami, dan dipikirkan. Sastra menurut ahli merupakan sastra sebagai karya lisan atau tulisan yang memiliki berbagai ciri keunggulan seperti keorisinalan, keartistikan, keindahan dalam isi, dan ungkapanya, (2) sastra adalah suatu bentuk dan hasil pekerjaan seni kreatif yang objeknya adalah manusia dan kehidupannya menggunakan bahasa sebagai mediumnya (Sudjiman, 1986:68; Semi, 1988:8).Sastra memiliki fungsi yaitu (1) berfungsi sebagai hiburan, (2) memiliki fungsi didaktik atau berfungsi untuk mendidik, (3) memiliki fungsi sosial yang lebih tinggi, (4) berfungsi mengungkapkan nilai-nilai kemanusiaan. Menurut Moody (dalam Endraswara, 2011:290-291), kajian sastra mempunyai peranan yang sangat penting dalam dunia pendidikan. Pembelajaran sastra saat ini sudah dicantumkan dalam kurikulum di jenjang pendidikan SD, SMP, dan SMA. Salah satu pembelajaran sastra yang dikatakan sangat kompleks dan penting adalah pembelajaran drama.

Pembelajaran drama sangat penting diajarkan kepada siswa dengan tujuan 
siswa mampu mengapresiasi, mempertunjukkan salah satu tokoh dalam karya sastra khususnya pembelajaran drama. Sehubungan dengan itu, Sastrowardoyo (dalam Emzir, dkk 2016:271) menyatakan bahwa manfaat utama pembelajaran drama bagi siswa adalah (1) memupuk kerjasama yang baik dalam pergaulan siswa, (2) memberi kesempatan bagi siswa untuk melahirkan daya kreasi masing-masing, (3) mengembangkan pengendalian emosi siswa, (4) menghilangkan sifat malu, gugup dan lain-lain. Dalam Kurikulum 2013 untuk siswa Sekolah Menengah Atas (SMA) kelas XI, pembelajaran drama terdapat beberapa KD (kompetensi dasar) yang harus terpenuhi. Dari KD tersebut ada dalam KI-3 yaitu memahami, menerapkan, menganalisis, dan mengevaluasi.

Drama merupakan suatu karya sastra yang ditulis dalam bentuk dialog yang diperagakan/ dipertunjukkan oleh aktor di panggung dan berdasarkan sebuah naskah. Pembelajaran drama sangat berperan dalam meningkatkan keterampilan siswa. Selama ini dalam pengajaran pembelajaran drama masih kekurangan waktu saat proses mengajar berlangsung. Untuk mengatasi hal ini peran guru sangat penting dalam pembelajaran. Agar terpenuhinya semua KD tentunya perlu pengelolaan pembelajaran yang baik.

Pengelolaan pembelajaran tersebut meliputi perencanaan pembelajaran, pelaksanaan perencanaan, memilih teknik evaluasi yang sesuai, dan melakukan evaluasi untuk ketercapainya tujuan pembelajaran. Menurut Sulistyari (2012:5) pengelolaan pembelajaran adalah sebagai jenis kegiatan yang dengan sengaja dilakukan oleh guru, dengan tujuan untuk menciptakan dan mempertahankan kondisi yang optimal bagi terjadinya proses belajar-mengajar. Perencanaan merupakan sebagai suatu proses dan cara berpikir yang dapat membantu menciptakan hasil yang diharapkan. Pelaksaan pembelajaran merupakan operasional atau kegiatan pembelajaran yang dilaksanakan berdasarkan perencanaan. Evaluasi pembelajaran adalah kegiatan mengukur dan menilai sesuatu produk dari kegiatan perencanaan dan pelaksanaan pembelajaran. Menurut Hamdayama (2016:194) evaluasi adalah suatu proses menentukan nilai prestasi pembelajaran dengan menggunakan patokan tertentu guna mencapai tujuan pengajaran yang telah ditetapkan sebelumnya. Teknik evaluasi merupakan tahapan yang digunakan untuk memperkuat dan mendukung ketiga kegiatan pembelajaran tersebut. Perencanaan, pelaksanaan, hasil evaluasi, dan teknik evaluasi merupakan kegiatan pembelajaran yang harus dilakukan oleh guru guna untuk mengetahui ketercapaian proses pembelajaran berlangsung. Hal itulah yang mendorong penelitian ini dilakukan. Penelitian ini bertujuan untuk mendeskripsikan (1) perencanaan pembelajaran drama di kelas XI IBB SMA N 1 Tejakula, (2) pelaksanaan pembelajaran drama di kelas XI IBB SMA N 1 Tejakula, (3) hasil evaluasi pembelajaran drama di kelas XI IBB SMA N 1 Tejakula, serta (3) teknik evaluasi pembelajaran drama di kelas XI IBB SMA N 1 Tejakula.

\section{METODE PENELITIAN}

Rancangan penelitian yang digunakan dalam penelitian ini adalah rancangan deskriptif kualitatif. Rancangan ini digunakan sebagai prosedur untuk mendeskripsikan fenomena yang terjadi pada saat penelitian ini berlangsung. Penelitian ini diajukan untuk mendeskripsikan pembelajaran drama. Rancangan penelitian deskriptif ini bertujuan untuk mendeskripsikan pembelajaran drama di kelas XI IBB SMA Negeri 1 Tejakula. 
Penggunaan rancangan penelitian deskriptif kualitatif memberikan gambaran secara sistematis, akurat, dan lebih menekankan pada data faktual. Rancangan ini dipilih karena sesuai dengan tujuan penelitian, yaitu untuk mendeskripsikan tentang perencanaan, pelaksanaan, hasil evaluasi, serta teknik evaluasi pembelajaran drama yang dilakukan oleh guru bahasa dan sastra Indonesia kelas XI IBB SMA Negeri 1 Tejakula..

Data penelitian ini dibatasi hanya pada pembelajaran drama semester genap kelas XI IBB. Subjek penelitian ini adalah guru bahasa Indonesia kelas XI IBB SMA Negeri 1 Tejakula. sedangkan objeknya adalah pembelajaran drama.

Data penelitian dikumpulkan dengan tiga metode, yakni metode observasi, wawancara, dan dokumentasi. Data tentang perencanaan pembelajaran diambil dari RPP guru melalui metode wawancara dan dokumentasi. Peneliti mencermati perencanaan pembelajaran pada RPP. Apabila terdapat hal yang belum dapat dimengerti, peneliti langsung menanyakan kepada guru bersangkutan. Data tentang pelaksanaan pembelajaran diperoleh melalui metode observasi.

Observasi partisipasi pasif dilakukan di kelas saat kegiatan pembelajaran berlangsung dengan mengamati guru saat melakukan pembelajaran di kelas serta pengambilan gambar. Data tentang hasil evaluasi pembelajaran diperoleh melalui metode dokumentasi. Metode dokumentasi digunakan untuk hasil evaluasi ini guna dijadikan bukti bahwa hasil yang diperoleh sesuai dengan yang diharapkan. Data tentang teknik evaluasi pembelajaran drama diperoleh melalui metode observasi. Metode ini digunakan guna untuk melihat dan mengamati teknik evaluasi yang digunakan guru saat proses pembelajaran berlangsung. Analisis data melalui tiga tahap, yaitu (1) reduksi data, (2) penyajian data, serta (3) penarikan simpulan.

\section{HASIL DAN PEMBAHASAN}

Hasil penelitian ini mencangkup (1) perecanaan pembelajaran drama di kelas XI IBB SMA Negeri 1 Tejakula, (2) pelaksanaan pembelajaran drama di kelas XI IBB SMA Negeri 1 Tejakula, (3) hasil evaluasi pembelajaran drama di kelas XI IBB SMA Negeri 1 Tejakula, (4) teknik evaluasi pembelajaran drama di kelas XI IBB SMA Negeri 1 Tejakula.

Dalam tahap perencanaan guru terlebih dahulu membuat perangkat pembelajaran. Perangkat pembelajaran yang disusun guru berupa silabus, RPP, media pembelajaran, dan asesmen/penilaian. Silabus yang disusun oleh guru mencakup komponen standar kompetensi, kompetensi dasar, materi pokok pembelajaran, kegiatan pembelajaran, indikator, penilaian, alokasi waktu, dan sumber/bahan/alat belajar. Silabus yang digunakan guru berdasarkan Kurikulum 2013. RPP yang disusun oleh guru didasarkan pada Permendikbud No 37 tahun 2018. Komponen-komponen yang terdapat dalam RPP meliputi identitas RPP, Kompetensi Inti (KI), Kompetensi Dasar (KD), indikator, tujuan, materi pembelajaran, metode pembelajaran, media, alat, sumber belajar, kegiatan pembelajaran, dan penilaian.

Pada bagian identitas yang dicantumkan oleh guru dalam RPP, meliputi satuan pendidikan, mata pelajaran, kelas/semester, program, tema, materi pokok, pertemuan, dan alokasi waktu. Kompetensi Inti dan Kompetensi Dasar disusun berdasarkan salinan Permendikbud Nomor 37 Tahun 2018 tentang Perubahan atas Permendikbud Nomor 24 Tahun 2016. Kompetensi inti (KI) yang dijabarkan dalam RPP buatan guru adalah kompetensi inti sikap spiritual, kompetensi inti sikap sosial, kompetensi inti pengetahuan, dan kompetensi inti keterampilan. 
Pada pembelajaran drama terdapat empat KD yang harus terpenuhi. Kompetensi dasar yang dibuat oleh guru sesuai dengan silabus mata pelajaran bahasa Indonesia kelas XI. Indikator dijabarkan berdasarkan Kompetensi Dasar (KD). Pembelajaran drama untuk kelas XI ada empat KD yang harus dituntaskan. Pertama KD Mengidentifikasi alur cerita, babak demi babak, dan konflik dalam drama yang dibaca atau ditonton. Indikator yang dijabarkan untuk KD yang pertama, (1) menjelaskan alur dalam drama yang dibaca atau ditonton, (2) menjelaskan babak dalam drama yang dibaca atau ditonton, (3) menganalisis konflik drama yang dibaca atau ditonton, (4) menjelaskan penokohan dalam drama yang dibaca atau ditonton. KD kedua, Menganalisis isi dan kebahasaan drama yang dibaca atau ditonton. Indikator pencapaian yang harus terpenuhi yaitu (1) menjelaskan isi drama yang dibaca atau ditonton, (2) mengidentifikasi kebahasaan drama yang dibaca atau ditonton, dan (3) mendeskripsikan persiapan mementaskan drama. KD ketiga, Mempertunjukkan salah satu tokoh dalam drama yang dibaca atau ditonton secara lisan. Indikator yang harus terpenuhi yaitu tentang mementaskan salah satu tokoh dalam drama yang dibaca atau ditonton secara lisan. KD terakhir, Mendemonstrasikan sebuah naskah drama dengan memerhatikan isi dan kebahasaan. Indikator pencapaian pada KD ini hanya mengenai mempresentasikan sebuah naskah drama dengan memerhatikan isi dan kebahasaan.

Tujuan pembelajaran yang disusun oleh guru dalam RPP ini mencakup beberapa tujuan yang terdapat pada pembelajaran drama seperti : (1) agar siswa dapat menjelaskan alur dalam drama yang dibaca atau ditonton, (2) siswa dapat menjelaskan babak dalam drama yang dibaca atau ditonton, (3) dapat menganalisis konflik drama yang dibaca atau ditonton, (4) dapat menjelaskan penokohan dalam drama yang dibaca atau ditonton. Pada materi pembelajaran guru hanya membuat subsub judul materi pembelajar.

Pada RPP ini guru menggunakan pendekatan, strategi, dan metode pembelajaran, guru menggunakan pendekatan saintifik menggunakan model Problem Based Learning, dan menggunakan metode pembelajaran teknik ATM (Amati, Tiru, dan Modifikasi), diskusi kelompok, ceramah, tanya jawab, penugasan, dan bermain peran. Pada media, alat, dan sumber belajar, guru menggunakan media bahan tayang untuk memaparkan materi dan menggunakan contoh-contoh teks drama. Alat yang digunakan papan tulis, buku pelajaran, laptop, LCD Proyektor,. Sumber belajar yang digunakan oleh guru, buku pelajaran, buku LKS, dan buku paket pedoman guru yaitu buku, (a) Kementerian Pendidikan dan Kebudayaan. 2017. Buku Siswa Mata Pelajaran Bahasa Indonesia Kelas XI Jakarta : Kementerian dan Kebudayaan, (b) Kementerian Pendidikan dan Kebudayaan. 2017. Buku Guru Mata Pelajaran Bahasa Indonesia Kelas XI Jakarta : Kementerian dan Kebudayaan, (c) Sumber lain yang relevan. Dalam RPP yang dibuat guru juga sudah mencantumkan langkag-langkah pembelajaran.

Pada RPP yang disusun oleh guru, tertera lima buah penilaian yang mencakup penilaian pengetahuan, sikap, dan keterampilan. Pada penilaian pengetahuan, guru menggunakan bentuk tes lisan maupun tulis, serta penugasan. Pada penilaian keterampilan, guru menggunakan bentuk penilaian presentasi atau pementasan. Sementara pada penilaian sikap, guru menggunakan bentuk penilaian observasi. Selain itu, guru juga mencantumkan lampiranlampiran seperti penugasan, lembar pengamatan, lembar observasi dan rubric 
penilaian ranah sikap dan keterampilan. Penilaian lain yang digunakan oleh guru, penilaian remedial dan penilaian pengayaan.

Pelaksanaan pembelajaran drama,
Guru menggunakan tiga tahap
pelaksanaan yaitu: (1) kegiatan
pendahuluan, (2) kegiatan inti, dan (3) kegiatan penutup. Kegiatan pendahuluan yang dilakukan oleh guru diawali dengan mengucapkan salam pembukaan selamat pagi (panganjali umat), dan berdoa sesuai agamanya sebelum memulai pembelajaran. Guru juga melakukan administrasi kelas, dengan menanyakan siswa yang tidak masuk sekolah, mengisi jurnal kelas, dan mengisi buku agenda guru, melihat kesiapan peserta didik sebelum pembelajaran dimulai. Guru juga melakukan apersepsi dengan melakukan tanya jawab mengenai materi sebelumnya.

Pada kegiatan inti guru membimbing siswa untuk memahami materi yang bersangkutan dengan cara mengamati (stimullasi), menanya (identifikasi masalah), mencoba (pengumpulan data), menalar (pengolahan data), dan mengomunikasikan (pembuktian). Kegiatan penutup guru dan peserta didik melakukan refleksi dan membuat kesimpulan tentang materi pembelajaran yang telah berlangsung. Selain itu guru juga memberikan tugas kepada peserta didik (PR) dan mengingatkan untuk mempelajari materi yang sudah diajarkan. Kemudian guru dan peserta didik menyepakati tugas yang dikerjakan di rumah dan mengingatkan peserta didik untuk mempelajari materi yang akan dibahas dipertemuan berikutnya maupun mempersiapkan diri menghadapi tes/evaluasi akhir dipertemuan berikutnya. Setelah pemberian tugas dan tes, maka guru mengakhiri pembelajaran. Sebelum mengakhiri pembelajaran guru dan peserta didik melakukan doa bersama, dan memberikan salam penutup.
Hasil evaluasi pembelajaran drama, di SMA N 1 Tejakula ini sudah dikatakan baik, siswa sangat antusias mengikuti pembelajaran. Nilai KKM 70 yang di gunakan guru dapat tercapai. Nilai yang dicapai siswa lebih banyak mendapat nilai 70. Ada juga yang mendapat nilai 80 bahkan 95. Siswa pada kelas XI berjumlah 36 siswa. Dari hasil ini guru dapat menentukan jenis penilaian yang digunakan. Dapat juga dijadikan sebagai penentu untuk penggunaan pendekatan, metode, strategi, dan media yang cocok untuk digunakan saat pembelajaran akan dilakukan. Nilai yang diperoleh oleh siswa itu didapat dari berbagai evaluasi yang dilakukan. Evaluasi yang dilakukan guru dengan menggunakan penilaian sikap, pengetahuan, keterampilan, remedial, dan pengayaan. Pada sikap yang dinilai ada dua, sikap spiritual dan sosial. Dengan menggunakan berbagai bentuk evaluasi.

Teknik pelaksanaan pembelajaran drama, guru menggunakan penilaian ranah kompetensi pengetahuan yang terdapat pada RPP yang disusun oleh guru selalu mencantumkan bentuk/jenis penilaian yang digunakan untuk menilai kemampuan pengetahuan siswa terhadap pemahaman materi yang dijelaskan. Guru menggunakan empat bentuk penilaian pengetahuan yaitu : tes lisan, penugasan, tes tertulis, dan portofolio dengan inatrumen terlampir.Penilaian kompetensi keterampilan guru menggunakan empat jenis/bentuk penilaian yaitu praktik, produk, proyek, dan portofolio dengan instrument penilaian terlampir. Pada penilaian sikap ini ada dua yang dinilai, pertama penilaian sikap spiritual dan kedua penilaian sikap sosial teman. Penilaian kompetensi sikap ini guru menggunakan penilaian observasi, penilaian diri, dan penilaian antar teman dengan bentuk isntrumen berupa jurnal serta butir instrumennya terlampir. Tidak hanya penilaian sikap, keterampilan, dan pengetahuan yang digunakan oleh guru. 
Tetapi guru juga menggunakan penilaian remedial dan pengayaan.

Penilaian remedial ini diberikan kepada peserta didik jika nilai yang diperoleh siswa belum mencapai KKM maupun yang sudah mencapai KKM. Remidial terdiri atas dua bagian yaitu remedial karena belum mencai KKM dan remedial karena belum mencapai ketuntasan Kompetensi Dasar. Tujuan penilaian ini untuk mengetahui batas pemahaman peserta didik terhadap materi pembelajaran serta sebagai acuan dan semangat peserta didik untuk lebih mendalami materi yang diberikan. Setelah remedial guru juga melakukan penilaian pengayaan. Penilaian ini dilakukan untuk menambah wawasan peserta didik mengenai materi yang telah diberikan dan telah mencapai ketuntasan. Selanjutnya penugasan yang guru berikan berupa tugas tertulis berbentuk essay, pilihan ganda, benar-salah, menjodohkan, isian, atau yang lainnya. Penugasan ini juga dapat diberikan saat pembelajaran berlangsung dan dapat dikerjakan di rumah.

\section{PEMBAHASAN}

Berdasarkan hasil penelitian di atas, pembelajaran drama di kelas XI IBB SMA $\mathrm{N} 1$ Tejakula. Hasil temuan dalam penelitian ini dianalisis secara deskriptif kualitatif, yaitu dibahas dengan cara mendeskripsikan atau menggambarkan tentang hal yang ditemukan dengan katakata.

Dalam tahap perencanaan pembelajaran drama, langkah awal yang disusun oleh guru dengan membuat perangkat pembelajaran. Perangkat pembelajaran yang disusun guru berupa silabus, RPP, media pembelajaran, dan evaluasi/penilaian. Perencanaan yang dalam bentuk RPP K13, disusun berdasarkan silabus K13 mata pelajaran bahasa Indonesia kelas XI. Perencanaan pembelajaran meliputi penyusunan rencana pelaksanaan pembelajaran, penyiapan media dan sumber belajar, perangkat penilaian pembelajaran, dan sekenario pembelajaran. Adapun komponen-komponen yang ada dalam RPP yang disusun oleh guru, meliputi identits RPP, Kompetensi Inti (KI), Kompetensi Dasar (KD), indikator, tujuan, materi pembelajaran, metode pembelajaran, media, alat, sumber belajar, kegiatan pembelajaran, dan penilaian. Komponen-komponen pada RPP yang disusun oleh guru telah sesuai dengan salinan lampiran Permendikbud Nomor 37 Tahun 2018 tentang perubahan Permendikbud Nomor 24 Tahun 2016.

Guru menggunakan pendekatan saintifik dan metode teknik ATM (Amati, Tiru, dan Modifikasi) diskusi, ceramah, tanya jawab, bermain peran, dan penugasan. Guru juga menggunakan model Problem Based Learning dalam proses pembelajarannya. Guru mencantumkan pendekatan pembelajaran saintifik. Guru mengungkapkan bahwa, pendekatan saintifik digunakan pada kegiatan pembelajaran drama karena ingin membuat peserta didik secara aktif mengonstruksi konsep, prinsip-prinsip melalui tahapan mengamati (untuk mengidentifikasi atau menemukan masalah), merumuskan masalah, mengajukan atau merumuskan hipotesis, mengumpulkan data dengan berbagai teknik, menganalisis data, menarik kesimpulan dan mengomunikasikan konsep, prinsip yang "ditemukan". Hal ini sejalan dengan pemikiran Kemendikbud melalui Materi Diklat Guru Implementasi Kurikulum 2013 Selain itu guru juga menggunakan metode pembelajaran seperti, diskusi, ceramah, tanya jawab, bermain peran, dan penugasan dalam penyampaian materi pembelajara.

Guru juga merancang penggunaan media pembelajaran. Guru menggunakan media pembelajaran. guru menggunakan media internet dan media visual berupa teks (buku paket). Media visual yang digunakan guru berupa teks. Menurut 
guru teks adalah media paling praktis dan bisa digunakan oleh setiap guru. Karena kepraktisannya guru memilih media teks. Dengan menggunakan media teks guru dapat membagikannya satu persatu kepada siswa. Dalam kegiatan pembelajaran guru melakukan beberapa langkah kegiatan yaitu kegiatan pendahuluan, kegiatan inti, kegiatan penutup. Menurut salinan lampiran Permendikbud 81A Tahun 2013, ada tiga langkah-langkah dalam pembelajaran yaitu pendahuluan, inti, dan penutup. Untuk penilaian guru menggunakan penilaian sikap, penilaian pengetahuan, penilaian keterampilan, penilaian remedial, dan penilaian pengayaan. Sejalan dengan Direktorat Jenderal Pendidikan Dasar dan Menengah Kementrian Pendidikan dan Kebudayaan (2015), penilaian hasil pembelajaran mencakup beberapa hal seperti penilaian sikap, pengetahuan, keterampilan.

Pelaksanaan pembelajaran drama adalah implementasi dari perencaan yang disusun oleh guru. Meskipun perencanaan pembelajaran bagus, perencanaan tidak akan berguna jika tidak diimplementasikan. Berdasarkan hasil observasi, pelaksanaan pembelajaran drama telah terlaksana dengan baik dan sesuai dengan perencanaan pembelajaran yang telah disusun. Guru tepat waktu sampai di ruang kelas. Ketepatan guru dalam memasuki ruang kelas, dapat menjadi contoh yang baik bagi siswa dalam hal kedisiplinan waktu. Kegiatan yang dilaksanakan guru di dalam kelas, yaitu kegiatan pendahuluan, kegiatan inti, dan kegiatan penutup. Langkah-langkah pembelajaran pada kegiatan pendahuluan yang disusun oleh guru dalam RPP setiap pertemuan terdapat delapan poin kegiatan. Poin-poin kegiatan pendahuluan yang telah disusun oleh guru dalam RPP tersebut sudah dilaksanakan dengan baik di dalam kelas.

Pada kegiatan awal pembelajaran guru berusaha untuk mengajak siswa untuk aktif bertanya dan mengemukakan pendapat. Guru juga memberikan penguatan secara verbal bagi yang sudah mencoba menjawab.Kegiatan inti sudah sesuai dengan pendekatan saintifik. Sejalan dengan salinan lampiran Permendikbud 81A Tahun 2013, pada kegiatan inti harus sesuai dengan pendekatan saintifik yang meliputi, mengamati, menanya, mencoba, menalar, dan mengomunikasikan (5M).

Kegiatan penutup yang dilakukan guru pada pelaksanaan pembelajaran yaitu, dengan memberikan tes lisan dan tes tulis. Tes lisan yang diberikan oleh guru dirasakan belum bisa memberikan gambaran yang akurat terhadap kemampuan peserta didik dalam memahami materi mengenai pembelajaran drama. Pelaksanaan pembelajaran drama sudah sesuai dengan langkah-langkah kegiatan pembelajaran yang tertuang dalam RPP. Guru sudah melaksanakan pembelajaran mulai dari tahap pendahuluan, inti, dan penutup. Guru juga sudah memberikan penguatan kepada siswa baik kepada siswa yang benar menjawab maupun yang menjawab kurang tepat.

Hasil pembelajaran drama sangat memuaskan. Seluruh siswa tuntas dalam pembelajaran. hal ini menunjukkan bahwa proses yang baik dalam pembelajaran akan menghasilkan pembelajaran sesuai dengan hal yang direncanakan oleh guru. Hasil pembelajaran dikatakan baik terlihat dari nilai yang diperoleh oleh peserta didik. Dalam satu kelas jumlah peserta didik sebanyak 36 siswa. Nilai yang diperoleh oleh siswa tidak ada dibawah KKM. Peserta didik yang mendapat nilai tertinggi ada enam siswa dengan perolehan nilai 95. Untuk siswa yang lain ada yang memperoleh nilai 70 ada juga yang memperoreh nilai 80 . Ketuntasan ini guru dapatkan dari evaluasi yang digunakan. Evaluasi yang digunakan guru ada tiga, penilaian sikap, keterampilan, pengetahuan, remedial, dan pengayaan. 
Teknik evaluasi pembelajaran drama. Guru melakukan penilain formal dengan menggunakan penilaian pengetahuan dan penilaian keterampilan peserta didik. penilaian informal yang dilakukan guru menggunakan penilaian sikap. guru melakukan penilaian dengan memperhatikan tiga ranah kemampuan peserta didik yaitu, pengetahuan, keterampilan, dan sikap.Penilaian Kompetensi Pengetahuan pada pembelajaran drama, guru selalu menggunakan empat bentuk penilaian pengetahuan, yaitu tes lisan, penugasan, tes tertulis, dan portofolio. Penilaian kompetensi keterampilan terdapat empat bentuk penilaian keterampilan yang dapat guru manfaatkan yaitu, penilaian untuk kerja, proyek, portofolio, dan produk. Penilaian kompetensi sikap ada tiga teknik dalam melakukan penilaian sikap, yaitu observasi, penilaian diri, dan penilaian antar teman. Selain itu guru juga menggunakan penilaian remedial dan pengayaan jika nilai yang diharapkan tidak tercapai.

\section{SIMPULAN DAN SARAN}

Simpulan dalam penelitian ini yaitu (1) Perencanaan pembelajaran drama pada siswa Kelas XI IBB SMA Negeri 1 Tejakula dilakukan oleh guru dengan menyusun perangkat pembelajaran yang terdiri atas silabus, RPP, media pembelajaran, dan evaluasi. (2) Pelaksanaan pembelajaran drama pada siswa Kelas XI IBB SMA Negeri 1 Tejakula sesuai dengan tahapan pembelajaran dalam Kurikulum 2013. Pendekatan saintiik dalam pembelajaran drama dikolaborasikan dengan metode ATM, problem based learning, bermain peran, ceramah, dan diskusi. (3) Hasil evaluasi pembelajaran drama pada siswa Kelas XI IBB SMA Negeri 1 Tejakula sangat baik, peserta didik sangat antusias mengikuti pembelajaran, semua peserta didik mendapatkan nilai di atas KKM, tidak ada siswa yang remidi, 6 orang siswa memperoleh nilai tertinggi dengan nilai 95 . Peserta didik yang lain memperoleh nilai 70 sampai 80. (4) Teknik evaluasi pembelajaran drama pada siswa Kelas XI IBB SMA Negeri 1 Tejakula dilakukan dengan menggunakan tes tertulis, tes lisan, proyek, penugasan dan remedial.

Saran yang dapat disampaikan dalam penelitian ini yaitu : (1) Bagi guru, hasil penelitian ini menunjukkan perencanaan, pelaksanaan, hasil belajar, dan teknik evaluasi yang digunakan oleh guru dalam pembelajaran mampu menuntaskan tujuan pembelajaran drama. Guru disarankan agar menggunakan perangkat pembelajaran, metode, media, dan teknik evaluasi sebagai salah satu alternatif cara membelajarkan siswa dalam pembelajaran drama. Guru juga diharapkan mampu memanfaatkan internet untuk menambah wawasan yang akan diberikan kepeserta didik. (2) Bagi siswa, disarankan untuk memanfaatkan, menerapkan pengalaman dan ilmu yang telah diperoleh agar dapat dijadikan bekal untuk terus mengembangkan bakat serta pemahamannya tentang bermain peran, teori-teori drama, berbicara di depan orang banyak, dan kepercayaan diri yang dimiliki sebagai modal untuk ke jenjang sekolah yang lebih tinggi. (3) Bagi sekolah, diharapkan dapat terus mendukung pengembangan pembelajaran drama serta terus melengkapi sarana dan prasarana seperti gedung/aula untuk pertunjukkan, peralatan akting dan pementasan yang dibutuhkan untuk menunjang keberhasilan dan meningkatkan nilai ketuntasan 70 menjadi 80 seperti yang diharapkan dapat tercapai dalam pembelajaran drama di kelas XI IBB SMA Negeri 1 Tejakula. (4) Bagi peneliti lain, disarankan agar melakukan penelitian mengenai pembelajaran drama dilihat dari : strategi, perangkat pembelajaran, metode, media, teknik evaluasi, dan hasil belajar mengajar di jenjang sekolah lainya seperti SMP karena penelitian ini dilakukan di jenjang 
pendidikan SMA. Dapat juga dijadikan pedoman untuk pembanding melakukan penelitian yang berkaitan dengan pembelajaran drama.

\section{DAFTAR PUSTAKA}

Emzir,dkk. 2016. Teori dan Pengajaran

Sastra. Jakarta : PT. Raja Grafindo

Persada.

Endraswara, Suwardi. 2011. Metode Pembelajaran Drama Apresiasi, Ekspresi, dan Pengkajian. Yogyakarta : CAPS

Hamalik,Oemar.2002. Psikologi Belajar Mengajar. Bandung : Sinar BaruAlgensindo

Hamdayama, Jumantan. 2016. Metodologi Pengajaran. Jakarta : Bumi Angkasa.

Salinan Lampiran Peraturan Menteri Pendidikan dan Kebudayaan Nomor 24Tahun 2016 tentang Kompetensi Inti dan Kompetensi Dasar Pelajaran pada Kurikulum 2013 pada Pendidikan Dasar dan Pendidikan Menengah.

Salinan Lampiran Peraturan Menteri Pendidikan dan Kebudayaan Nomor 37Tahun 2018 Perubahan Atas Peraturan Menteri Pendidikan dan Kebudayaan Nomor 24 Tahun 2016

Salinan Lampiran Peraturan Menteri Pendidikan dan Kebudayaan Nomor 81ATahun 2013 tentang Implementasi Kurikulum Pedoman Umum Pembelajaran : Jakarta.

Semi, Atar.1988. Kritik Sastra. Bandung : Angkasa.

Sudjiman, P.1986. Kamus Istilah Sastra. Jakarta : Gramedia.

Sulistyari, Dewi Ratna. 2012. Pengelolaan Pembelajaran Guru : Studi Situs SMP

Negeri 2 Kartasuro Kabupaten Sukoharjo. 